\title{
ANALISIS RASIO KEUANGAN TERHADAP KONDISI FINANCIAL DISTRESS PADA PERUSAHAAN MANUFAKTUR YANG TERDAFTAR DI BURSA EFEK INDONESIA
}

\author{
Oleh \\ Muh. Fajrin Sirajuddin \\ Institut Bisnis dan Keuangan Nitro Makassar \\ Email: muh.fajrin148@gmail.com
}

\begin{abstract}
Abstrak
Penelitian ini bertujuan untuk memeriksa pengaruh rasio keuangan terhadap financial distress pada perusahaan manufaktur yang terdapat di Bursa Efek Indonesia (BEI) periode 2015-2019. Penelitian ini merupakan replika dan modifikasi dari penelitian Baimwera dan Muriuki (2014) yang menyatakan bahwa hanya rasio pertumbuhan dan profitabilitas yang signifikan mempengaruhu financial distress. Peneliti menggunakan enam variabel independen yang diduga dapat mempengaruhi terjadinya financial distress. Keenam variabel tersebut adalah Earning Before Interest and Tax to Total Asset(EBITTA), Working Capital to Total Asset (WCTA), Market Value of Equity to Book Value of Total Liability (MVTL), Retained Earnings to Total Asset (RETA), Sales to Total Asset (SATA), dan Cash Flows from Operating to Total Asset (CFOTA). Data diuji pada satu tahun dan dua tahun sebelum terjadinya financial distress.
\end{abstract}


Data yang digunakan dalam penelitian ini merupakan data sekunder yang diperoleh dari Indonesian Capital Market Directory (ICMD). Metode teknik sampling probabilitas digunakan untuk memilih sampel perusahaanyang memiliki status financial distress. Tipe acak sederhana digunakan untuk memilih perusahaan yang memiliki Earning per Share (EPS) negatif selama dua tahun berturut-turut selama tahun 2015 dan 2017. Kriteria pemilihan sampel tersebut menghasilkan 66 perusahaan yang dapat diteliti yang terdiri dari 33 perusahaan financial distress, 33 perusahaan non financial distress, dan 599 total observasi.

Hasil penelitian menunjukkan bahwa hanya rasio "Earning Before Interest and Tax to Total Asset" (EBITTA) yang berpengaruh terhadap kondisi financial distress baik pada satu atau dua tahun sebelum kejadian. Hasil analisis data dengan menggunakan regresi logistik menghasilkan ketepatan prediksi sebesar $69,4 \%$ pada satu tahun sebelum financial distress dan $54,2 \%$ pada dua tahun sebelum financial distress.

Kata Kunci: Financial Distress, rasio keuangan, earning per share, regresi logistik

\section{PENDAHULUAN}

Krisis ekonomi pada tahun 2008 yang bersumber dari Amerika Serikat berlanjut pada negara-negara lain yang mengakibatkan krisis ekonomi global. Indonesia merupakan salah satu negara yang tak luput dari goncangan krisis ekonomi ini. Kontraksi aktivitas bisnis di pasar 
internasional dan Non Performing Loan (NPL) naik dari 55,4 trilyun pada November 2008 menjadi 60,6 triliyun pada Maret 2009 (www.bi.go.id). Hal ini berimbas pada perekonomian di Indonesia karena Indonesia merupakan negara small open economy dan sangat sensitif terhadap faktor eksternal (www.setneg.go.id).

Banyak perusahaan yang terkena dampak goncangan krisis ekonomi pada tahun-tahun tersebut, tak terkecuali perusahaan manufaktur. Perusahaan manufaktur merupakan perusahaan terbanyak yang terdaftar di Bursa Efek Indonesia. Perusahaan ini dapat mendorong pertumbuhan perekonomian secara cepat dan stabil bagi keseluruhan perekonomian Indonesia (World Perusahaan Office Jakarta, 2012). Perusahaan manufaktur mengalami penurunan kinerja akibat krisis Asia pada tahun 1997-1998. Setelah terjadi krisis ekonomi dan politik, pertumbuhan industri manufaktur menurun yang berdampak pada kecilnya kontribusi pada PDB riil.

Menurut data BPS, rata-rata pertumbuhan output pada periode sebelum krisis (1991-1995) mencapai 22\%, sedangkan pada periode setelah krisis (2002-2006) menurun menjadi 12\%. Pada tahun 2012 BPS mencatat pertumbuhan industri manufaktur mengalami pertumbuhan negatif. Data menunjukkan pertumbuhan furniture menurun sebesar $15.85 \%$, tekstil sebesar $15.38 \%$, dan pertumbuhan industri dan peralatan anjlok sebesar $12.94 \%$. Terjadi penurunan produksi pada sektor kulit, barang dari kulit, dan alas kaki sebesar 9.67\%. 
Hal yang sama dialami oleh industri kertas dan barang dari kertas yang turun sebesar $8.38 \%$, begitu juga logam dasar turun sebanyak 1.84\%. Pada tahun 2013 sektor aneka industri mengalami penurunan sebesar $11 \%$ sehingga menjadi penekan kinerja indeks. Pada triwulan II tahun 2014 industri manufaktur pada sektor industri tekstil, jasa reparasi dan pemasangan mesin, serta industri percetakan dan reproduksi media rekaman mengalami penurunan produksi.

Perusahaan yang terus menunjukkan kinerja yang menurun dikhawatirkan akan mengalami kondisi financial distress yang berujung pada kebangkrutan perusahaan. Kesulitan keuangan atau financial distress adalah keadaan dimana perusahaan menemui kesulitan atau bahkan tidak bisa untuk membayar kewajiban keuangannya kepada para kreditur (Ahmad Khaliq dkk, 2014). Sedangkan menurut Platt dan Platt dalam Almilia, financial distress adalah turunnya kondisi keuangan suatu perusahaan sebagai indikator sebelum terjadinya kebangkrutan

Beberapa peneliti mengkatagorikan kondisi financial distress dalam berbagai kriteria. Perusahaan dianggap mengalami financial distress ketika salah satu dari kondisi ini terpenuhi (1) perusahaan yang mengalami rugi selama tiga tahun berturut-turut atau lebih (2) perusahaan yang memiliki arus kas negatif selama tiga tahun atau lebih (Lakhsan, 2013). Ardiyanto pada tahun 2011 menggunakan Earning Per Share (EPS) negatif selama beberapa tahun untuk penentuan kondisi distress 
perusahaan sesuai dengan penelitian Elloumi dan Gueyie pada tahun 2001. Fitriyah dan Hariyati pada tahun 2013 menyatakan bahwa perusahaan yang mengalami financial distress yaitu perusahaan yang memiliki EPS negatif dua tahun berturut-turut.

Penelitian ini akan menggunakan EPS (Earning Per Share) negatif untuk menentukan kriteria perusahaan yang mengalami financial distress. EPS merupakan laba yang diharapkan per lembar saham. EPS banyak digunakan untuk mengevaluasi kinerja operasi dan profitabilitas perusahaan. Perusahaan dianggap memiliki pertumbuhan yang baik apabila memiliki EPS positif secara terus menerus (Whittaker dalam Ardiyanto, 2011).

Financial distress penting untuk dipelajari karena berfungsi sebagai tanda bahwa suatu perusahaan akan bangkrut sehingga dapat dilakukan tindakan antisipatif untuk mencegah hal tersebut. Model prediksi financial distress perlu dikembangkan untuk membantu manajer dalam mengawasi kinerja perusahaan dan membantu mengidentifikasi tren yang penting (Ray, 2011). Para kreditur juga dapat menggunakan model ini untuk menilai kinerja perusahaan sehingga dapat dideteksi apakah perusahaan mampu mengembalikan pinjamannya. Lembaga pembuat kebijakan dan peraturan juga dapat menggunakan model ini untuk mengawasi apakah perusahaan berada pada situasi yang buruk sehingga dapat dikeluarkan peraturan yang sesuai. 
Rasio keuangan banyak digunakan untuk dianalisis dan selanjutnya menjadi model prediksi kebangkrutan. Rasio keuangan dapat menggambarkan keadaan pada masa lampau, sekarang, dan akan datang sebagai indikator yang sangat berguna yang bisa dihitung dari laporan keuangan (Khaliq dkk, 2014). Menurut Mohammad et al (2009) dalam Khaliq dkk (2014) rasio keuangan berperan penting dalam menganalisis kinerja perusahaan dan memperhitungkan kegagalan perusahaan melalui praktik aplikasi. Para peneliti yang mengembangkan model prediksi kebangkrutan mengakui bahwa rasio keuangan adalah salah satu alat prediksi financial distress karena rasio keuangan dapat merefleksikan kondisi keuangan perusahaan (Lakhsan dan Wijekoon, 2013)

Banyak penelitian telah dilakukan untuk menjelaskan model prediksi kebangkrutan atau financial distress pada perusahaan yang menggunakan rasio keuangan. Penelitian awal dilakukan oleh Altman (1968) yang menganalisis rasio keuangan sebagai alat untuk memprediksi kebangkrutan perusahaan (Ghozali, 2012). Rasio-rasio keuangan yang digunakan adalah working capital/total assets, retained earnings/total assets, earnings before interest and taxes/total assets, market value equity/book value of total debt, sales/total assets. Rasio keuangan tersebut terbukti bisa digunakan untuk memprediksi terjadinya kebangkrutan perusahaan (Almilia \& Kristijadi, 2003) 
Penelitian lain dilakukan oleh Lakhsan dan Wijekoon yang berjudul The Use of Financial Ratios in Predicting Corporate Failure in Sri Lanka pada tahun 2013. Hasilnya hanya rasio working capital to total asset, debt ratio, dan cash flow from operating activities to total asset yang berpengaruh signifikan dalam memprediksi kesulitan keuangan perusahaan.

Berdasarkan dari penelitian-penelitian terdahulu, peneliti tertarik untuk melihat pengaruh beberapa rasio keuangan pada kondisi financial distress pada perusahaan manufaktur yang terdaftar di Bursa Efek Indonesia (BEI). Penelitian ini mengacu pada penelitian yang telah dilakukan oleh Baimwera dan Muriuki yang berjudul Analysis of Corporate Financial Distress Determinants: A Survey Of Non Financial Firms Listed In The Nse (2014). Penelitian ini menggunakan analisis regresi untuk memeriksa hubungan antara faktor financial distress perusahaan dan financial distress itu sendiri. Hasil menunjukkan likuiditas dan leverage memiliki pengaruh yang tidak signifikan dalam menentukan financial distress. Sedangkan pertumbuhan dan profitabilitas memiliki pengaruh yang signifikan dalam menentukan financial distress perusahaan.

Perbedaan penelitian ini dengan penelitian sebelumnya adalah digunakannya variabel yang terdapat pada rasio Altman dan rasio arus kas untuk melihat pengaruhnya terhadap kondisi financial distress perusahaan manufaktur. Rasio arus kas disertakan karena terdapat beberapa kritikan pada saat rasio Altman digunakan secara individu untuk 
menganalisis terjadinya financial distress. Sharma dan Iselin (dalam Lakhsan, 2013) menyatakan bahwa model Altman tidak memasukkan rasio arus kas untuk memprediksi financial distress. Rasio arus kas sebaiknya dimasukkan untuk analisis karena rasio ini dapat menjadi alternatif untuk meminimalkan resiko terjadinya window-dressing. Hal ini dikarenakan sistem akrual menawarkan banyak kesempatan untuk manipulasi semacam itu.

Hipotesis akan diuji dalam dua periode, yaitu satu tahun dan dua tahun sebelum terjadinya financial distress. Hal ini disebabkan karena model prediksi kebangkrutan merupakan alat prediksi yang akurat hingga dua tahun sebelum terjadinya kesulitan keuangan, dan jika jangka waktunya bertambah akurasinya akan menurun (Hartoyo, 2012). Alat analisis yang digunakan adalah model regresi logistik. Peneliti mengambil sampel penelitian dari data sekunder laporan keuangan yang diterbitkan oleh perusahaan-perusahaan tersebut untuk tahun 2008-2013.

Financial distress merupakan penurunan kinerja keuangan sebelum terjadi kebangkrutan. Kesulitan keuangan berkisar dari kesulitan likuiditas (jangka pendek) sampai kebangkrutan (jangka panjang). Analisis financial distress penting untuk dilakukan agar para pihak yang berkepentingan bisa melakukan perbaikan sebelum terjadi kebangkrutan. Data-data akuntansi bisa digunakan untuk memprediksi sinyal-sinyal kebangkrutan ini. 
Penelitian ini akan menganalisis pengaruh kelima rasio keuangan Altman dan rasio arus kas terhadap kemungkinan terjadinya financial distress. Rasio-rasio tersebut akan diuji pada satu dan dua tahun sebelum kejadian untuk melihat perbedaan dan tingkat akurasinya. Sejauh ini masih sedikit teori yang mengarah pada penelitian kebangkrutan, misalnya pada variabel-variabel yang dianggap relevan (mamduh, 2000). Penelitian-penelitian terdahulu juga menunjukkan perbedaan rasio-rasio keuangan apa yang berpengaruh terhadap kesulitan keuangan sehingga diperlukan penelitian lebih lanjut.

Dengan demikian, peneliti tertarik melakukan penelitian dengan judul

"Analisis Rasio Keuangan Terhadap Kondisi Financial Distress Pada Perusahaan Manufaktur yang terdaftar di Bursa Efek Indonesia “

\section{TINJAUAN PUSTAKA}

\section{A. Landasan Teori dan Penelitian Terdahulu}

\section{Financial Distress}

Khaliq dkk (2014) mendefinisikan financial distress sebagai suatu kondisi dimana perusahaan tidak bisa atau mengalami kesulitan untuk memenuhi kewajibannya kepada kreditur. Peluang terjadinya financial distress meningkat ketika biaya tetap perusahaan tinggi, aset likuid, atau pendapatan yang sangat sensitif terhadap resesi ekonomi. Kondisi ini akan memaksa perusahaan untuk mengeluarkan biaya yang tinggi sehingga 
manajemen terpaksa melakukan pinjaman kepada pihak lain. Baimwera dan Muriuki pada tahun 2014 juga mendefinisikan financial distress sebagai kemungkinan dimana perusahaan tidak dapat memenuhi kewajibannya pada saat jatuh tempo.

Elloumi dan Gueyie (dikutip oleh Fitriyah, 2013) mendefinisikan financial distress sebagai perusahaan yang memiliki laba per lembar saham (earning per share) negatif. Prospek perusahaan di masa depan dapat dilihat dari pertumbuhan laba per lembar saham yang nantinya akan mempengaruhi keputusan investor untuk menanamkan modalnya di perusahaan tersebut. EPS yang negatif dalam beberapa tahun menunjukkan pertumbuhan perusahaan yang kurang baik sehingga investor kurang tertarik untuk berinvestasi. Hal ini akan meningkatkan potensi perusahaan untuk mengalami financial distress karena perusahaan akan sulit untuk mendapatkan dana.

Platt dan Platt (dikutip oleh Almilia, 2003) menyatakan bahwa financial distress adalah tahap penurunan kondisi keuangan sebelum terjadi kebangkrutan. Pada saat terjadi kesulitan keuangan, ketidakmampuan perusahaan untuk memenuhi kewajiban menunjukkan bahwa perusahaan tersebut kekurangan modal kerja atau working capital (Aghaei, 2013). Kekurangan modal kerja ini dapat disebabkan oleh beberapa faktor, seperti kewajiban lancar dan biaya operasi yang terlalu tinggi. Jika perusahaan mengalami financial distress dan tidak ada tindakan lebih lanjut 
untuk perbaikan, perusahaan dapat mengalami kebangkrutan bahkan dapat dilikuidasi. Kebangkrutan adalah keadaan dimana perusahaan gagal atau tidak mampu lagi memenuhi segala kewajiban pemberi pinjaman (debitur) karena perusahaan kekurangan dana untuk menjalankan dan melanjutkan usahanya sehingga pencapaian tujuan ekonomi tidak terpenuhi (Wongsosudono, 2013).

Terdapat perusahaan yang mengalami financial distress dan terdapat pula perusahaan yang dibubarkan setelah mengalami financial distress. Lau (dikutip oleh Aghaei, 2013) menyatakan bahwa terdapat lima fase kebangkrutan perusahaan, yaitu:

1. Zero point: kondisi keuangan perusahaan masih stabil

2.First phase: pengurangan atau pengeleminasian pada pembayaran deviden kas

3. Second phase: kegagalan teknikal atau penurunan likuiditas perusahaan untuk memenuh kewajiban jangka pendeknya

4. Third phase: kewajiban perusahaan melebihi nilai aset

5. Fourth phase: pengumuman sah kebangkrutan dan likuidasi perusahaan

Banyak penelitian yang mengkatagorikan perusahaan yang mengalami financial distress secara berbeda. Perusahaan dianggap mengalami financial distress ketika salah satu dari kondisi ini terpenuhi (1) perusahaan yang mengalami rugi selama tiga 
tahun berturut-turut atau lebih (2) perusahaan yang memiliki arus kas negatif selama tiga tahun atau lebih (Lakhsan, 2013). Almilia dan Kristijadi memilih perusahaan yang memiliki laba bersih operasi negatif dan selama lebih dari satu tahun tidak membayar deviden sebagai perusahaan yang mengalami financial distress. Pranowo dkk pada tahun 2010 menyatakan bahwa perusahaan yang memiliki Debt Service Coverage Ratio (DSCR) $<1.2$ sebagai perusahaan distress. Ardiyanto pada tahun 2011 menggunakan Earning Per Share (EPS) negatif selama beberapa tahun untuk penentuan kondisi distress perusahaan sesuai dengan penelitian Elloumi dan Gueyie pada tahun 2001.

Model prediksi financial distress perlu dikembangkan agar dapat diketahui tindakan-tindakan yang perlu dilakukan untuk mengantisipasi kebangkrutan. Pihak-pihak yang memerlukan model prediksi ini menurut Ray (2011):

1. Manajer perusahaan: model prediksi dapat memotivasi manajer untuk mengidentifikasi masalah dan mengambil tindakan yang efektif untuk mengurangi kemungkinan distress.

2. Auditor: model ini dapat memberi peringatan dini kepada auditor yang lalai dan melindungi mereka terhadap tuntutan atas kelalaian tersebut karena tidak menyingkap kemungkinan kesulitan keuangan perusahaan. 
3.Pemberi pinjaman: model ini dapat digunakan untuk menilai kegagalan perusahaan terhadap pinjamannya.

4.Lembaga pembuat peraturan: lembaga ini akan mengawasi perusahaan apakah berada pada tanda bahaya kesulitan keuangan.

Menurut Fooster (dikutip oleh Mulyaningrum, 2008) ada beberapa indikator terjadinya kebangkrutan perusahaan, antara lain:

1. Analisis arus kas pada periode sekarang dan yang akan datang

2.Analisis strategi perusahaan yang meliputi pesaing potensial, struktur biaya relatif, perluasan rencana dalam industri, kemampuan perusahaan untuk meneruskan kenaikan biaya, kualitas manajemen dan lain sebagainya

3.Analisis laporan keuangan suatu perusahaan dengan perusahaan lain

4. Variabel eksternal seperti return sekuritas dan penilaian obligasi

\section{Laporan Keuangan dan Rasio Keuangan}

Pernyataan Standar Akuntansi Keuangan (PSAK) No 1 mendefinisikan laporan keuangan sebagai suatu penyajian terstruktur dari posisi keuangan dan kinerja keuangan suatu entitas. Laporan keuangan mencerminkan kemajuan dan kemunduran 
suatu perusahaan dalam periodik (Yuanita, 2010). Kebanyakan peneliti menggunakan laporan keuangan untuk dianalisis dan menjelaskan prediksi financial distress. Laporan keuangan dapat menghasilkan informasi yang dapat digunakan untuk membuat keputusan mengenai investasi dan pendanaan (Almilia dan Kristijadi, 2003).

Seperti yang tertuang dalam Pernyataan Standar Akuntansi Keuangan (PSAK) No 1 bahwa laporan keuangan bertujuan untuk memberikan informasi mengenai posisi keuangan, kinerja, dan arus kas perusahaan yang bermanfaat bagi para penggunanya untuk membuat keputusan ekonomi. Laporan keuangan ini juga merupakan bentuk pertanggungjawaban oleh manajemen terhadap berbagai sumber daya yang dipercayakan kepada mereka. Laporan keuangan memberikan informasi mengenai: (1) aset, (2) kewajiban, (3) ekuitas, (4) pendapatan dan beban termasuk keuntungan dan kerugian, dan (5) arus kas.

Rasio-rasio keuangan yang terdapat didalam laporan keuangan dapat dianalisis untuk mendapatkan informasi mengenai kinerja keuangan. Kebanyakan peneliti mengembangkan model prediksi kegagalan keuangan mengakui bahwa rasio keuangan adalah salah satu prediksi utama financial distress karena rasio keuangan dapat mewakili kondisi perusahaan (Lakhsan, 2013). Rasio keuangan melalui analis laporan keuangan digunakan untuk 
mengukur kondisi financial distress suatu perusahaan (Hapsari, 2012).

\section{Earning Per Share (EPS)}

Laba per lembar saham (earning per share/ EPS) adalah laba yang diharapkan per lembar saham. Data EPS banyak digunakan untuk mengevaluasi kinerja operasi dan profitabilitas perusahaan (Subramanyam dan John, 2011). Data ini terutama digunakan oleh pemegang saham biasa untuk menilai kinerja perusahaan daripada deviden yang dibagikan. Biasanya data ini akan mempengaruhi harga saham di pasaran (Rahardjo, 2005). Umumnya perhitungan EPS sudah tersaji dalam perhitungan laba rugi di dalam laporan keuangan suatu perusahaan.

Beberapa penelitian menyatakan bahwa EPS berhubungan erat dengan financial distress. Seperti yang dinyatakan oleh Elloumi dan Gueyie (dalam Ardiyanto, 2011) bahwa financial distress diartikan sebagai perusahaan yang memiliki EPS negatif. Pernyataan selanjutnya diberikan oleh Tandelilin (dalam Saleh, 2013) bahwa EPS berguna bagi para investor untuk melihat prospek laba perusahaan di masa depan. Perusahaan dianggap memiliki pertumbuhan yang baik jika memiliki EPS positif secara terus menerus (Whitaker, 1999). Jika yang terjadi sebaliknya, investor akan sangsi untuk menanamkan dana di perusahaan tersebut karena pertumbuhan perusahaan di masa depan tidak baik. Hal ini 
akan memicu terjadinya kondisi financial distress akibat perusahaan kekurangan dana.

\section{Model Altman Z score}

Menurut Bemmann pada tahun 2005 (dalam Ray, 2011) model Altman $Z$ score merupakan model yang banyak dikenal dan dipraktikkan untuk memprediksi financial distress. Model ini pertama kali dikembangkan oleh Prof. Edward I. Altman yang mengumpulkan data 33 perusahaan yang mengalami kebangkrutan, 33 yang tidak pada perusahaan manufaktur tahun 1946-1965. Penelitian ini dilakukan dengan menggunakan analisis diskriminan dan menghasilkan lima variabel untuk prediksi financial distress. Variabel-variabel tersebut adalah working capital/total assets, retained earnings/total assets, earnings before interest and taxes/total assets, market value equity/book value of total debt, dan sales/total assets.

Fungsi diskriminan yang terbentuk adalah:

$$
\begin{aligned}
& \mathrm{Z}=1.2 \mathrm{X} 1+1.4 \mathrm{X} 2+3.3 \mathrm{X} 3+0.6 \mathrm{X} 4+1.0 \mathrm{X} 5 \\
& \text { Dimana }: \mathrm{XI}=\text { Working capital/ total asset }(\mathrm{WC} / \mathrm{TA}) \\
& \mathrm{X} 2=\text { Retained earnings/total asset }(\mathrm{RE} / \mathrm{TA}) \\
& \mathrm{X} 3=\mathrm{EBIT} / \text { total asset }(\mathrm{EBIT} / \mathrm{TA}) \\
& \mathrm{X} 4=\text { Market value of equity/book value of liability }(\mathrm{MVE} / \mathrm{TL}) \\
& \mathrm{X} 5 \text { = Sales/total asset (S/TA) } \\
& \mathrm{Z}=\text { indeks keseluruhan kebangkrutan }
\end{aligned}
$$


$Z$ score $<1.81=$ perusahaan memiliki kesulitan keuangan yang besar dan beresiko tinggi terkena kebangkrutan

$Z$ score $>3$ = perusahaan memiliki kemungkinan yang rendah terkena kebangkrutan

$1,81<Z$ score $<3$ = grey area $/$ daerah abu-abu yaitu daerah dimana perusahaan berbagi karakteristik keuangan antara distress atau tidak dan harus diteliti secara cermat sebelum terlambat melakukan tindakan pencegahan.

Model ini telah digunakan oleh banyak peneliti untuk diaplikasikan dalam pengklasifikasian perusahaan di banyak negara. Seperti yang dilakukan oleh El Khoury dan Al Beaino pada tahun 2013 yang mengaplikasikan Model Altman untuk mengklasifikasi perusahaan manufaktur di Lebanon. Bukti menunjukkan bahwa model ini bermanfaat untuk memberikan informasi kepada bank, perusahaan, dan investor. Suatu bank dapat menggunakan informasi ini untuk mengklasifikasikan kliennya apakah masuk ke dalam kondisi distress atau tidak. Perusahaan dapat menggunakan informasi ini untuk mengevaluasi kinerjanya. Sedangkan informasi tersebut dapat digunakan oleh investor sebagai alat untuk membandingkan saham di perusahaan yang berbeda.

Penelitian selanjutnya dilakukan oleh Grice dan Ingram pada tahun 2001 yang menganalisis apakah model Altman bisa digunakan pada periode, industri, dan kondisi keuangan secara 
umum yang berbeda dengan apa yang digunakan oleh Altman. Hasil menunjukkan bahwa tingkat akurasi model ini menurun pada periode yang berbeda dan model ini signifikan hanya pada perusahaan manufaktur. Hasil selanjutnya menunjukkan bahwa jika siapapun yang menggunakan model ini harus mengestimasi kembali koefisien model dan tidak tergantung pada hasil kesimpulan Altman.

\section{Arus Kas}

Arus kas merupakan selisih antara arus kas masuk dan keluar pada periode yang sedang berjalan. Arus kas ini berbeda dengan kinerja akrual yang terletak pada pengakuan beban dan pendapatannya. Arus masuk akan diakui ketika terdapat kas masuk walaupun belum dihasilkan dan arus keluar akan diakui saat kas dibayarkan walaupun belum tentu terjadi beban. Laporan arus kas berisi dari tiga elemen, yaitu arus kas dari aktivitas operasi, investasi, dan pendanaan. Laporan ini berguna untuk memberikan informasi mengenai kemampuan perusahaan untuk memenuhi kewajibannya, membayar deviden, meningkatkan pendanaan, asumsi tentang arus kas masa depan, dan lain-lain (Subramanyam dan John, 2011).

Penelitian yang menggunakan analisis arus kas ini sudah banyak dilakukan oleh peneliti-peneliti terdahulu. Analisis arus kas ini penting karena perusahaan harus memiliki kemampuan jangka pendek untuk memenuhi operasional perusahaan. Selain itu 
kemampuan jangka panjang juga dibutuhkan untuk mendapatkan kas dari sumber eksternal (Pancawardani, 2009). Hal ini akan memberikan gambaran mengenai keadaaan kas perusahaan dan mampu memberikan sinyal sebagai antisipasi penghindaran kondisi financial distress perusahaan.

Beberapa penelitian yang telah dilakukan terkait penggunaan arus kas ini adalah penelitian Wijayanti pada tahun 2014 yang membandingkan pendekatan berbasis akrual dan arus kas untuk memprediksi kondisi financial distrees di perusahaan manufaktur. Alat statistik yang digunakan adalah model diskriminan analisis. Hasil menunjukkan bahwa model prediksi kebangkrutan berbasis arus kas memiliki kemampuan sama baiknya dengan model akrual, yaitu dengan tingkat ketepatan prediksi sebesar $50 \%$. Selain itu juga terdapat penelitian yang dilakukan oleh Pancawardani pada tahun 2009 yang mengukur kinerja keuangan perusahaan menggunakan metode analisa cash flow ratio. Hasil menunjukkan bahwa rasio-rasio cash flow dapat dijadikan metode alternatif untuk mengukur kinerja suatu perusahaan.

\section{Rasio-rasio Keuangan}

Rasio-rasio keuangan umumnya merupakan gabungan angkaangka yang terdapat di neraca, laporan laba rugi, dan laporan arus kas. Rasio menggambarkan hubungan matematis antara suatu jumlah dengan jumlah yang lain. Analisis rasio keuangan ini akan memberi gambaran kepada penganalisis mengenai baik buruknya 
kinerja keuangan (Munawir, 1999). Beberapa rasio-rasio keuangan yang akan digunakan dalam penelitian ini adalah sebagai berikut:

\section{a) Profitability Ratio}

Rasio ini digunakan untuk melihat kemampuan perusahaan dalam menghasilkan profitabilitas pada tingkat penjualan, asset, dan modal saham tertentu. Rasio yang biasa digunakan adalah Earning Before Interest and Tax to Total Assetto Total Asset (EBITTA). EBITTA merupakan alat yang digunakan untuk mengukur produktivitas aset-aset perusahaan, terlepas dari pajak atau faktor leverage (Altman, 2000). Analisis ini digunakan untuk mengukur kemampuan perusahaan dalam mengelola sumber dayanya secara efektif yang dapat dilihat dari hasil penjualan dan investasinya (Ray, 2011). Rasio ini mengukur produktivitas dari aset-aset perusahaan untuk menghasilkan laba.Menurut Altman (2000) EBITTA merupakan rasio yang sesuai untuk studi mengenai kegagalan perusahaan karena keberlangsungan perusahaan dinilai berdasarkan kemampuan menghasilkan laba dari asetnya.

\section{b) Liquidity Ratio}

Rasio likuiditas mengukur kemampuan perusahaan untuk dapat memenuhi kewajiban-kewajiban jangka pendeknya. Rasio ini berguna untuk bank, kreditor jangka pendek, manajemen, dan kreditor jangka panjang. Bank dan kreditor jangka pendek menggunakan rasio ini untuk menganalisa dan 
menginterpretasikan posisi keuangan jangka pendek, sedangkan manajemen menggunakannya untuk melihat efisiensi modal kerja yang digunakan perusahaan. Prospek, deviden, dan pembayaran bunga juga dapat dilihat melalui analisis rasio ini yang berguna bagi kreditor jangka panjang dan pemegang saham (Munawir, 1999).

Working capital to total asset merupakan ukuran asset lancar perusahaan dengan total kapitalisasinya (Lakhsan, 2013). Rasio ini menunjukkan kemampuan perusahaan untuk menghasilkan modal kerja bersih dari seluruh total asset yang dimilikinya. Modal kerja ini digunakan untuk membiayai operasi perusahaan atau menanggulangi kesulitan-kesulitan keuangan yang mungkin terjadi. Modal kerja bersih yang positif menunjukkan tidak tersedianya asset lancar yang cukup untuk menutupi kewajiban jangka pendeknya sehingga memiliki kemungkinan kecil untuk menghadapi masalah.

Sebaliknya modal kerja negatif berkemungkinan besar mengalami kesulitan dalam memenuhi kewajiban jangka pendeknya (Fitriyah, 2013). Penurunan pada working capital dapat menyebabkan penurunan pada dana yang likuid yang dapat menghalangi dalam membeli dan mengakumulasi persediaan yang akan berakibat pada kekurangan persediaan. Di sisi lain ini juga mengindikasikan debitor yang lebih sedikit yang dapat menyebabkan kredit macet lebih kecil sehingga 
akan berpengaruh pada efisiensi organisasi secara keseluruhan (Ray, 2011).

\section{c) Leverage Ratio}

Rasio ini menunjukkan kemampuan perusahaan dalam membiayai pendanaan dengan menggunakan sumber dana untuk meningkatkan keuntungan pemegang saham dan pihak eksternal. Rasio yang tinggi menunjukkan proporsi pembiayaan hutang yang tinggi dibandingkan pembiayaan ekuitas. Leverage yang tinggi akan meningkatkan pengembalian saat kondisi bisnis yang menguntungkan, dan sebaliknya (Baimwera dan Muriuki, 2014). Ekuitas diukur dengan memadukan nilai pasar pada semua saham, baik saham biasa maupun saham preferen. Sedangkan liabilitas merupakan kombinasi dari kewajiban jangka pendek dan jangka panjang. Pengukuran ini menunjukkan berapa banyak penurunan nilai asset perusahaan sebelum liabilitas melebihi asset sehingga terjadi kebangkrutan (Altman, 2000).

\section{d) Growth Ratio}

Rasio ini menunjukkan tingkat pertumbuhan sebuah perusahaan yang dapat diraih tanpa harus meminjam danaatau pemasukan modal dari pihak lain. Rasio ini diukur dengan menggunakan salah satu variabel Altman, yaitu Retained Earnings by Total Aset. Rasio ini merupakan indikator yang menunjukkan efisiensi manajemen dalam mengelola produksi, 
penjualan, administrasi, dan aktivitas lainnya (Ray, 2011). Rasio yang tinggi menunjukkan bahwa investasi sebagian besar dibiayai dari retained earnings daripada ekuitas dan utang dari luar (Baimwera, 2014). Perusahaan yang memiliki rasio yang tinggi juga menunjukkan bahwa perusahaan tersebut membiayai asetnya melalui labanya sehingga tidak menggunakan hutang yang besar (Altman, 2000). Sebaliknya, rasio yang rendah menunjukkan bahwa adanya kemungkinan pertumbuhan tidak berlanjut jika perusahaan tersebut dibiayai oleh utang yang tinggi dan bukan pada labanya (Kumar dan Anand, 2013).

\section{e) Capital Turnover Ratio}

Rasio perputaran modal ini merupakan rasio keuangan standar yang menggambarkan kemampuan asset perusahaan dalam menghasilkan penjualan. Rasio ini merupakan rasio yang penting karena merupakan rasio yang paling sedikit tingkat signifikannya pada basis individual. Pada uji signifikasi univariat rasio ini tidak akan terlihat sama sekali. Namun dalam hubungannya dengan variabel lain didalam model, rasio ini memiliki kemampuan diskriminan dalam model (Altman, 2000). Rasio yang tinggi menunjukkan bahwa perusahaan menggunakan asetnya secara efisien untuk meningkatkan penjualan, dan sebaliknya. Kinerja keuangan dan profitabilitas berfokus pada pendapatan penjualan (Ray, 2011). 


\section{f) Cash Flow Ratio}

Rasio arus kas ini juga berguna untuk melihat kinerja perusahaan disamping rasio dari neraca dan laba rugi. Rasio ini berguna untuk melihat kemampuan perusahaan dalam menghasilkan arus kas di masa depan (Lakhsan, 2013). Sharma dan Iselin (dikutip oleh Lakhsan, 2013) menyatakan bahwa sistem akrual memberikan kesempatan kepada manajemen untuk melakukan window dressing akun-akun mereka, sehingga analisis cash flow sebaiknya disertakan karena informasi dari cash flow tersebut dapat menjadi sumber alternatif. Hal ini dikarenakan cash flow menyediakan lebih sedikit kesempatan untuk kegiatan manipulasi. Cash flow from operations to total asset menunjukkan kemampuan perusahaan dalam menghasilkan aliran kasnya melalui asset yang dimiliki (Lakhsan, 2013).

\section{Penelitian Terdahulu}

Banyak penelitian yang telah dilakukan untuk mengetahui pengaruh rasio keuangan terhadap terjadinya financial distress. Rasio keuangan ini nantinya akan diuji apakah berpebgaruh atau tidak berpengaruh secara signifikan terhadap kemungkinan terjadinya kegagalan keuangan. Penelitian awal dilakukan oleh Altman (1968) yang menganalisis rasio keuangan sebagai alat untuk memprediksi kebangkrutan perusahaan (Ghozali, 2012). Rasio-rasio keuangan yang digunakan adalah working capital/total 
assets, retained earnings/total assets, earnings before interest and taxes/total assets, market value equity/book value of total debt, sales/total assets. Rasio keuangan tersebut terbukti bisa digunakan untuk memprediksi terjadinya kebangkrutan perusahaan (Almilia dan Kristijadi, 2003).

Pada tahun 2014 dilakukan penelitian oleh Baimwera dan Muriuki yang berjudul Analysis of Corporate Financial Distress Determinants: A Survey Of Non Financial Firms Listed In The Nse (2014). Penelitian ini menggunakan analisis regresi untuk memeriksa hubungan antara faktor financial distress perusahaan dan financial distress itu sendiri. Variabel rasio keuangan yang digunakan adalah liquidity, profitability, leverage, dan firm's growth. Hasil menunjukkan likuiditas dan leverage memiliki pengaruh yang tidak signifikan dalam menentukan financial distress. Sedangkan pertumbuhan dan profitabilitas memiliki pengaruh yang signifikan dalam menentukan financial distress perusahaan.

Penelitian selanjutnya dilakukan oleh Lakhsan dan Wijekoon pada tahun 2013 yang menganalisis rasio keuangan untuk memprediksi kegagalan perusahaan di Sri Lanka. Penelitian ini menggunakan data laporan keuangan 70 perusahaan yang bangkrut dan 70 yang tidak pada tahun 2002-2008. Alat analisis yang digunakan adalah analisis regresi logistik. Hasilnya hanya tiga rasio yang memiliki kekuatan yang signifikan sebagai predictor 
kegagalan perusahaan, yaitu working capital to total asset, debt ratio, dan cash flow from operating activities to total asset.

Di Indonesia terdapat penelitian yang dilakukan oleh Pranowo dkk (2010) yang memeriksa kesehatan perusahaan non keuangan yang terdaftar di BEI. Alat analisis yang digunakan adalah regresi. Hasilnya current ratio, efficiency, equity, dan variabel dummy pada status kondisi keuangan adalah positif dan signifikan mempengaruhi Debt Service Coverage (DSC) sebagai proksi dari dalam financial distress. Sebaliknya, leverage, profit, retaired earning, good corporate governance, dan faktor makroekonomi tidak memiliki dampak signifikan dalam memprediksi financial distress perusahaan.

Pengaruh rasio keuangan terhadap kondisi financial distress juga diteliti oleh Widarjo dan Setiawan pada tahun 2009 dengan judul Pengaruh Rasio Keuangan Terhadap Kondisi Financial Distress perusahaan otomotif. Variabel yang digunakan adalah rasio likuiditas dan financial leverage ratio.Alat analisis yang digunakan adalah regresi logistik. Hasilnya adalah current ratio, cash ratio, total liabilities to total asset, current liabilities to total asset, dan pertumbuhan penjualan tidak berpengaruh terhadap financial distress perusahaan. Sedangkan quick ratio dan profitability berpengaruh negatif terhadap financial distress perusahaan. 
Penelitian lain juga dilakukan oleh Fitriyah dan Hariyati pada tahun 2013 yang berjudul Pengaruh Rasio Keuangan Terhadap Financial Distress Pada Perusahaan Properti dan Real Estate. Hipotesis diuji pada periode satu dan dua tahun sebelum terjadinya financial distress. Alat analisis data yang digunakan adalah analisis data regresi logistik. Variabel yang digunakan adalah current ratio (CA/CL), current asset to total asset (CATA), working capital to total asset (WCTA), long term debt to equity (LTDEQ), total liabilities to total asset (TLTA), earnings before interest and tax to total assets (EBITTA), net income to total assets (NITA), net income to equity (NIEQ). Hasil menunjukkan bahwa pada tahun pertama hanya EBITTA dan TLTA dan pada tahun kedua hanya NITA yang mempengaruhi terjadinya financial distress.

Penelitian lain juga dilakukan oleh Rosnaini Daga dengan penelitian PENGARUH STRATEGI KEMITRAAN BANK TERHADAP KEPUASAN NASABAH PADA PT. BANK MEGA Tbk. CABANG AHMAD YANI MAKASSAR dengan menggunakan metode analisis yang digunakan dalam penelitian ini adalah analisis deskriptif, analisis regresi linear berganda, uji validitas, uji reliabilitas, dan uji t. Dan hasil dari penelitian tersebut diambil kesimpulan. Dari hasil analisis dan pembahasan yang telah diuraikan pada bab sebelumnya, maka dapat ditarik beberapa kesimpulan dari hasil analisis yaitu : 
1. Berdasarkan hasil analisis regresi berganda yang telah dilakukan maka dapat disimpulkan bahwa strategi kemitraan yang terdiri dari : pemasaran yang berkelanjutan dan pemasaran secara individu mempunyai pengaruh yang positif dan signifikan terhadap kepuasan nasabah pada PT. Bank Mega, Tbk. Cabang Ahmad Yani Makassar

2. Dari hasil pengujian regresi maka dapat diketahui bahwa variabel dari strategi kemitraan yang paling dominan berpengaruh terhadap kepuasan nasabah pada PT. Bank Mega, Tbk. Cabang Ahmad Yani Makassar adalah pemasaran secara individu.

\section{B. Kerangka Pemikiran}

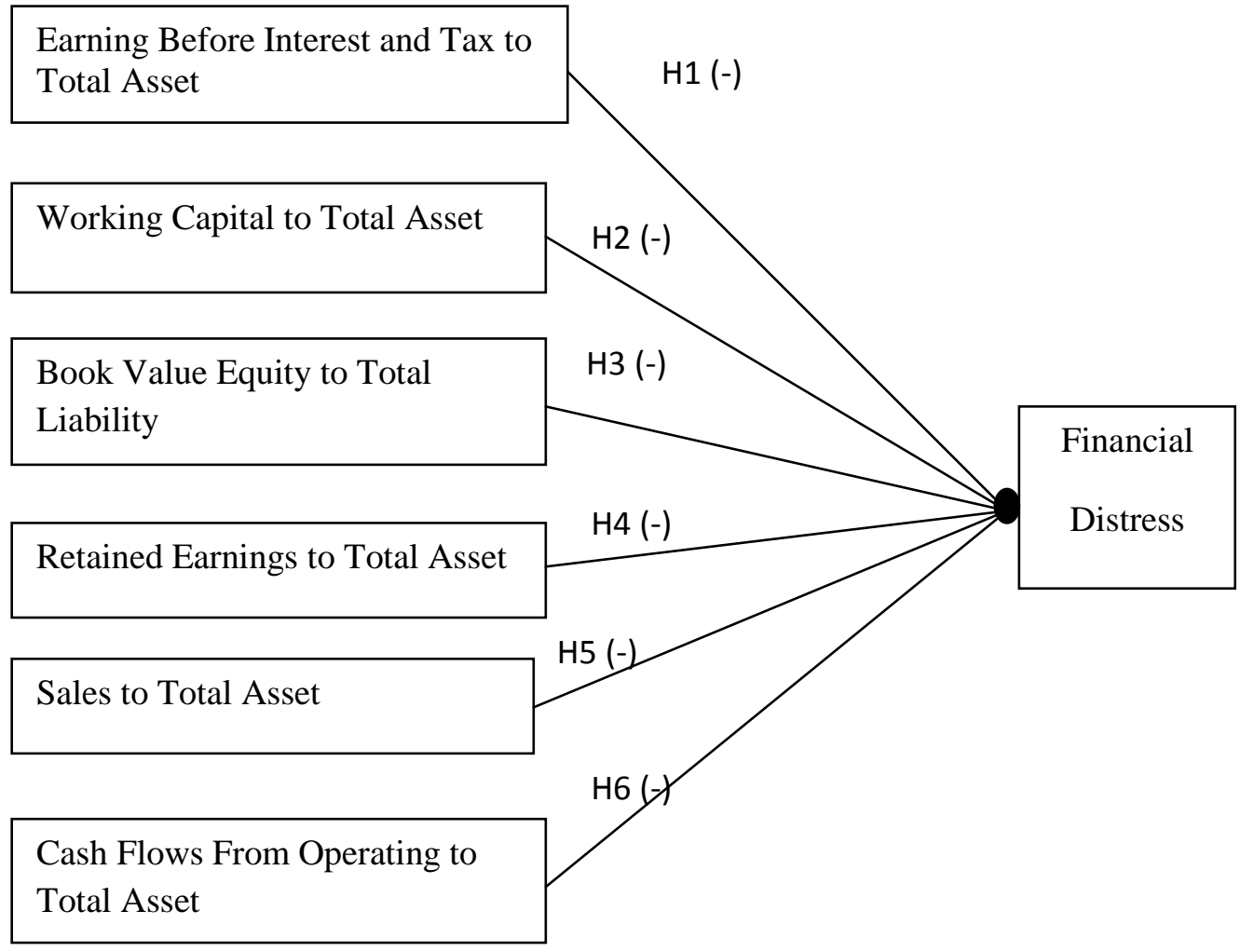


Penelitian ini menganalisis rasio-rasio keuangan untuk melihat pengaruhnya terhadap kesehatan suatu perusahaan sehingga dapat diketahui apakah perusahaan tersebut mengarah pada kebangkrutan atau tidak. Rasio-rasio keuangan yang digunakan adalah Earning Before Interest and Tax to Total Asset berpengaruh negatif, Working Capital to Total Asset berpengaruh negatif, Book Value Equity to Total Liability berpengaruh negatif, Retained Earnings to Total Asset berpengaruh negatif, Sales to Total Asset berpengaruh negatif, dan Cash Flow From Operating to Total Asset berpengaruh negatif.

\section{METOLOGI PENELITIAN}

\section{Lokasi dan Waktu Penelitian}

Penelitian ini dilakukan di Kantor Perwakilan BEI - PT Bursa Efek Indonesia yang berlokasi di Jl. A.P. Pettarani No.9 Kelurahan Sinri Jala, Kecamatan Panakkukang, Kota Makassar, Sulawesi Selatan, dengan waktu penelitian selama kurang lebih 1 (satu) bulan.

\section{Variabel Penelitian dan Definisi Opersaional}

Variabel dependen dalam penelitian ini adalah status perusahaan, apakah mengalami financial distress atau tidak. Sedangkan variabel independen yang digunakan adalah Earning Before Interest And Tax to Total Asset, Working Capital to Total Asset, Market Value of Equity to Book Value of Total Liabilities, Retained Earnings to Total Asset, Sales to 
Total Asset, dan Cash Flow From Operations to Total Asset. Adapun masing-masing variabel akan dijelaskan sebagai berikut:

\section{a. Earning Before Interest and Tax to Total Asset (EBITTA)}

Earning Before Interest and Tax to Total Asset (EBITTA) merupakan salah satu rasio profitabilitas. Analisis ini digunakan untuk mengukur kemampuan perusahaan dalam mengelola sumber dayanya secara efektif yang dapat dilihat dari hasil penjualan dan investasinya (Ray, 2011). Rasio EBITTA mengukur apakah aset-aset perusahaan digunakan secara rasional untuk menghasilkan laba dari kegiatan operasinya (Baimwera, 2014)

b. Working Capital to Total Asset (WCTA)

Working capital to total asset merupakan ukuran asset lancar perusahaan dengan total kapitalisasinya (Lakhsan, 2013). Rasio ini dihitung dengan membagi modal kerja dengan total asset. Rasio ini menunjukkan kemampuan perusahaan untuk menghasilkan modal kerja bersih dari seluruh total asset yang dimilikinya. Modal kerja ini digunakan untuk membiayai operasi perusahaan atau menanggulangi kesulitankesulitan keuangan yang mungkin terjadi (Fitriyah, 2013).

\section{c. Market Value Of Equity To Book Value Of Total Liability (MVTL)}

Rasio ini menunjukkan kemampuan perusahaan dalam membiayai pendanaan dengan menggunakan sumber dana untuk meningkatkan keuntungan pemegang saham dan pihak eksternal. Ekuitas diukur dengan 
memadukan nilai pasar pada semua saham, baik saham biasa maupun saham preferen. Sedangkan liabilitas merupakan kombinasi dari kewajiban jangka pendek dan jangka panjang. Pengukuran ini menunjukkan berapa banyak penurunan nilai asset perusahaan sebelum liabilitas melebihi asset sehingga terjadi kebangkrutan (Altman, 2000).

\section{d. Retained Earnings by Total Aset (RETA)}

Rasio ini menunjukkan tingkat pertumbuhan sebuah perusahaan yang dapat diraih tanpa harus meminjam dana atau pemasukan modal dari pihak lain. Rasio ini merupakan indikator yang menunjukkan efisiensi manajemen dalam mengelola produksi, penjualan, administrasi, dan aktivitas lainnya (Ray, 2011). Rasio yang tinggi menunjukkan bahwa investasi sebagian besar dibiayai dari retained earnings daripada ekuitas dan utang dari luar (Baimwera, 2014). Sebaliknya, rasio yang rendah menunjukkan bahwa adanya kemungkinan pertumbuhan tidak berlanjut jika perusahaan tersebut dibiayai oleh utang yang tinggi dan bukan pada labanya (Kumar dan Anand, 2013).

\section{e. Sales to Total Asset (SATA)}

Rasio perputaran modal ini merupakan rasio keuangan standar yang menggambarkan kemampuan asset perusahaan dalam menghasilkan penjualan Altman, 2000). Rasio yang tinggi menunjukkan bahwa perusahaan menggunakan asetnya secara efisien untuk meningkatkan 
penjualan, dan sebaliknya. Kinerja keuangan dan profitabilitas berfokus pada pendapatan penjualan (Ray, 2011).

\section{f. Cash Flow From Operations to Total Asset(CFOTA)}

Cash flow from operations to total asset menunjukkan kemampuan perusahaan dalam menghasilkan aliran kasnya melalui asset yang dimiliki (Lakhsan, 2013). Rasio arus kas meningkat berakibat pada laba yang naik, nilai perusahaan yang tinggi, dan kemungkinan terjadinya financial distress yang rendah (Almilia, 2006).

\section{Populasi dan sampel}

Penelitian ini menggunakan perusahaan manufaktur yang terdaftar di Bursa Efek Indonesia dari tahun 2015-2019 sebagai obyek penelitian. Metode teknik sampling probabilitas digunakan untuk memilih sampel. Jenis teknik sampling probabilitas yang digunakan adalah sampling acak sederhana. Sampling acak sederhana berarti setiap elemen akan memiliki probabilitas yang sama untuk terpilih (Neuman, 2013). Teknik ini menghasilkan sampel yang cenderung mewakili seluruh populasi. Sampel akan diambil sesuai dengan kriteria penelitian Luciana Spica Almilia \& Kristijadi (2003), seperti:

a) Perusahaan-perusahaan berbasis manufaktur yang memiliki laporan keuangan yang dipublikasikan di Bursa Efek Indonesia periode 2015-2019

b) Perusahaan yang tidak terbentuk selama tahun $2015-2019$ 
c) Kriteria perusahaan yang mengalami financial distress:

- perusahaan yang mengalami EPS negatif selama dua tahun berturut-turut

- data perusahaan yang akan olah adalah data perusahaan satu tahun dan dua tahun sebelum mengalami financial distress

d) sebagai kontrol dipilih perusahaan yang tidak mengalami financial distress:

- perusahaan yang mengalami EPS positif selama dua tahun berturut-turut yang memiliki kesamaan industri, tahun terjadinya financial distress, dan kemiripan ukuran asset dengan perusahaan yang mengalami financial distress.

- data perusahaan yang akan olah adalah data perusahaan satu tahun dan dua tahun sebelum mengalami laba positif

e) Laporan keuangan satu dan dua tahun sebelum terjadinya distress (EPS negatif) merupakan data yang akan diolah. Data tahun 20102013 digunakan sebagai pedoman untuk penentuan financial distress perusahaan. Sedangkan data tahun 2015-2018 merupakan data yang akan diolah.

\section{Jenis dan Sumber Data}

Data akan diperoleh dari data sekunder yang terdapat pada laporan keuangan auditan yang sudah terdaftar di Bursa Efek Indonesia dari tahun 
2015-2019. Situs resmi Bursa Efek Indonesia dan pojok BEI-UNDIP akan digunakan untuk mengambil data.

\section{Metode Pengumpulan Data}

Penelitian ini menggunakan dua metode dalam mengumpulkan data, yaitu dengan metode dokumentasi dan pencarian.Metode dokumentasi dilakukan dengan mempelajari data sekunder yang diterbitkan oleh Bursa Efek Indonesia dilanjutkan penghitungan sekaligus pencatatan. Metode pencarian dilakukan dengan cara mencari informasi melalui jurnal dan data yang tersedia melalui website resmi yang terdapat di internet.

\section{Metode Analisis Data}

Metode analisis data yang digunakan dalam penelitian ini adalah metode analisis data kuantitatif. Dalam metode ini informasi didapatkan dengan mengkuantisasi data-data penelitian. Penelitian ini menggunakan pengujian hipotesis analisis regresi, karena memiliki satu non-metrik dua kategori variabel dependen dan lebih dari satu metric variabel independen (Ghozali, 2011).

\subsection{Analisis Regresi}

Analisis regresi merupakan studi mengenai hubungan antara variabel dependen dengan satu atau lebih variabel independen yang bertujuan untuk memperkirakan nilai rata-rata variabel dependen berdasarkan nilai variabel independen yang diketahui (Gujarati, 2003). 
Ada bermacam-macam bentuk alat pengukuran dalam model regresi ini, diantaranya adalah:

a) Koefisien determinasi $\left(R^{2}\right)$

Pada intinya koefisien ini mengukur kemampuan model dalam menjelaskan variasi yang terdapat pada variabel dependen. Nilai koefisien determinasi adalah antara 0 dan 1 (Imam Ghozali, 2011). Kemampuan variabel-variabel independen dalam menjelaskan variasi variabel dependen amat terbatas akan ditunjukkan oleh nilai $\mathrm{R} 2$ yang kecil. Jika nilainya mendekati 1 berarti variabel independen dapat menjelaskan variasi yang terdapat pada variabel dependen.

b) Logistik regression

Logistic regression ini dapat digunakan untuk menguji apakah probabilitas terjadinya variabel terikat dapat diprediksi dengan variabel bebasnya (Imam Ghozali, 2011). Regresi logistik digunakan karena variabel dependennya berupa variabel dummy (non metrik) atau dapat diukur dengan skala nominal. Sedangkan variabel independennya diukur dengan skala rasio yang tidak perlu asumsi normalitas data. Dalam hal ini apakah financial distress dapat diprediksi dengan variabel seperti earning before interest and tax, working capital to total asset, book value equity to total liability, retained earnings by total asset, sales to total asset, dan cash flow from operating to total asset.

\subsection{Model regresi logistik yang terbentuk}


Alat analisis yang digunakan dalam penelitian ini adalah analisis regresi logistik. Model regresi logistik yang digunakan untuk menguji hipotesis dalam penelitian ini adalah:

Financial distress $=\operatorname{Ln} \frac{p}{1-p}=\mathrm{b} 0+\mathrm{b} 1 \mathrm{EBITTA}+\mathrm{b} 2 \mathrm{WCTA}+\mathrm{b} 3 \mathrm{MVTL}+$

$$
\text { b4RETA + b5SATA + b6CFOTA + e }
$$

Keterangan:

$\begin{array}{ll}\text { Y }=\operatorname{Ln} \frac{p(\text { tidak bermasala } h)}{1-p(\text { bermasala } h)} & =\text { status kegagalan perusahaan } \\ \text { b0 } & =\text { konstanta } \\ \text { b1 }-\mathrm{b} 6 & =\text { koefisien regresi } \\ \text { EBITTA } & \text { Esset } \\ \text { WCTA } & =\text { Working Capital to Total Asset } \\ \text { MVTL } & =\text { Book Value Equity to Total Liability } \\ \text { RETA } & =\text { Retained Earnings to Total Asset } \\ \text { SATA } & =\text { Sales to Total Asset } \\ \text { CFOTA } & =\text { Cash Flow From Operations to Total Asset }\end{array}$

\subsection{Uji Asumsi Klasik}

Langkah awal sebelum melakukan uji statistik adalah screening terhadap data yang akan diolah (Ghozali, 2011). Jika regresi berganda digunakan untuk mengolah data, pengujian hipotesis harus menghindari terjadinya penyimpangan uji asumsi klasih yang bertujuan agar tidak 
terjadi masalah dalam penggunaan analisis ini (Gujarati, 2005) dalam (Kamaludin, 2011). Oleh karena itu penelitian ini juga akan diuji hubungan antar variabelnya dengan uji multikolonieritas.

\subsubsection{Uji Multikolonieritas}

Tujuan uji ini adalah apakah terdapat korelasi antar variabel bebas (independen).Model regresi yang baik adalah yang tidak ada korelasi antar variabel independennya. Jika terjadi korelasi berarti korelasi antar variabel independennya tidak sama dengan 0 . Ada tidaknya multikolonieritas didalam model regresi dapat dideteksi dengan cara sebagai berikut:

a) Nilai $R^{2}$ yang dihasilkan oleh estimasi regresi empiris sangat tinggi

b) Jika antar variabel independen ada korelasi yang cukup tinggi, maka hal ini mengindikasikan adanya gejala multikolonieritas

c) Melihat nilai tolerance dan Variance Inflation Factor (VIF) yang menunjukkan setiap variabel independen manakah yang dijelaskan oleh variabel independen lainnya.

\section{KESIMPULAN}

Dari hasil penelitian ini menggunakan dua metode dalam mengumpulkan data, yaitu dengan metode dokumentasi dan pencarian. Metode dokumentasi dilakukan dengan mempelajari data sekunder yang diterbitkan oleh Bursa Efek Indonesia dilanjutkan penghitungan sekaligus pencatatan. Variabel dependen dalam penelitian ini adalah status perusahaan, apakah mengalami financial distress atau tidak. Sedangkan variabel independen yang digunakan adalah Earning Before Interest And 
Tax to Total Asset, Working Capital to Total Asset, Market Value of Equity to Book Value of Total Liabilities, Retained Earnings to Total Asset, Sales to Total Asset, dan Cash Flow From Operations to Total Asset. Dengan demikian kita akan mengetahui apakah perusahaan tersebut mengalami Financial Distress atau tidak. 


\section{DAFTAR PUSTAKA}

Aprica, Amelina dan A. Guna Dharma. 2010. "Rasio-rasio Keuangan, Analisa Diskriminan, dan Prediksi Probabilitas Kegagalan Perusahaan-perusahaan Pada Industri Properti dan Real Estate yang Listing diBursa EfekIndonesia". Jurusan Manajemen Fakultas Ekonomi, Universitas Kristen Maranatha.

Baimwera, Bernard dan Antony Murimi Muriuki. 2014. "Analysis Of Corporate Financial Distress Determinants : A Survey of NonFinancial Firms Listed In the NSE". International Journal of Current Business and Social Sciences, Vol1. Issue2

Bank Indonesia, 2008, Outlook Ekonomi Indonesia 2008-2013, edisi Juli 2008, BankI ndonesia.

Daga, R. (2021). PENGARUH STRATEGI KEMITRAAN BANK TERHADAP KEPUASAN NASABAH PADA PT. BANK MEGA Tbk. CABANG AHMAD YANI MAKASSAR.

Evanny Indri Hapsari. 2012. "Kekuatan Rasio Keuangan Dalam Memprediksi Kondisi Financial Distress Perusahaan Manufaktur di BEl”. Jurnal dinamika manajemen, Vol3. No. 2. Pp:101-109.

Fitriyah, Idadan Hariyati. 2013. "Pengaruh Rasio Keuangan Terhadap Financial Distress Pada Perusahaan Properti dan Real Estate". Jurnal Ilmu Manajemen, Vol1. No3. Mei 2011

Hanafi, Mamduh dan Abdul Halim. 2000. Analisis Laporan Keuangan. Yogyakarta: UPP AMP YKPN.

Hartoyo, Nico Tantra. 2012. "Prediksi Financial Distress Menggunakan Analisis Diskriminan Pada Perusahaan Manufaktur yang Terdaftar di Bursa Efek Indonesia Tahun 2010-2011". Jurnal Universitas Brawijaya.

Pancawardani, Nurul Latifah. 2009. "Pengukuran Kinerja Keuangan Perusahaan Dengan Metode Analisa Cash Flow Ratio. Fokus Ekonomi, Vol. 4 No. 2 Desember 2009 : 46-59. 